\title{
THE LINK BETWEEN ACCOUNTING AND FISCAL EVASION
}

\author{
Lăzărescu (Marinescu) Silvia, Economist \\ General Manager, Human Resources Organization, ANAF
}

\section{Abstract:}

In the literature, controversies have arisen concerning the link between accounting and fiscal evasion, which are the object of debates among specialists from different specialized organizations from many countries. Under the term of "creative accounting", the American and European tax systems have made up an ensemble of accounting mechanisms and also of fiscal manipulation which increased the interest and involvement of the states in the mitigation of such fraud risks and fiscal subterfuges whose percentage in the countries' GDP varies from 8 to $80 \%$. Starting from the SWOT analysis of tax evasion in the real and underground economy, the specialists of the liberal trades are called to join the fight against fiscal fraud and share their professionalism in creating a real competitive environment characterized by fair play.

Many accounting specialists define the connection between accounting and evasion as a concept named "creative accounting" that includes the interventions made on financial numbers and on the structure of transactions in order to alter the financial reports.

"Creative accounting" and "result management" are euphemisms used for accounting practices that deviate from accounting standards. They are characterized by the use of new intelligent means to determine the incomes, debts and receivables leading to results manipulating policies [Cernuşcă, L., Politici contabile de întreprindere, Editura Tribuna Economică, p.32-36]

The term "creative accounting" is found in both British and French literature.

In the beginning, around 1980, in England, the increase in corporate revenues was the result of accounting manipulation, as Ian Griffith pointed out: "each company in the country is fooling around when talking about its profits. Each set of financial statements is based on accounts that were cooked and fried over a low fire. That's the biggest trick ever since the Trojan Horse......." [Griffith, I., Creative Accounting, London: Sidgwick \& Jackson]

In an academic vision of 1993, Nasser defined creative accounting as "the transformation of accounting results from what they are into what they are wished to be, by using rules and/or by ignoring some of such rules to the advantage of accountants" [Nasser, K., Creative Financial Accounting: It's nature and use, Hemel Hempstead: Prentice Hall]

In France, creative accounting was defined and continues to be perceived as an art.

Bertolus defined it as "the art of baking accounts", Gounin as "the art of presenting a balance sheet" and Gillet stated that it consisted in "the totality of techniques, options and liberties found in accounting texts, which, without getting away from accounting norms and requirements leave company leaders the possibility to fiddle with the result or to modify the aspect of the synthetic accounting documents" [Bertolus, J., L'art de truquer un bilan, Science \& Vie economie, $n^{\circ} 40$, June, 1988]

Currently, the application of accounting standards has led to the existence of numerous calculation and accounting methods.

For instance, in the expansion years of the USA, the American companies "put aside" the capitals received from the Federal Government for expansion. Later on, such funds were counted as profit. We may ask ourselves whether this practice was fraud or just an accounting "game".

Situations that lead to the same kind of question are those referring to:

- recording the results from the sale of shares or of a part of a subsidiary as revenues; 
- recording barter transactions as revenues;

- recording in the books the entire selling price of an asset sold for a commission, instead of recording only the commission;

- recording rebates as publicity expenditures (deductible within the limits of the Fiscal Code);

- capitalization of marketing expenditures and so on.

- Such situations that raise the doubt of fraud or of a mere accounting subterfuge have been the subject of many accounting and tax experts.

On the one hand, KPMG launches the idea of introducing new managerial techniques for the consultants focused on the concept of managerial proxy, i.e. the delegation of responsibilities in taking decisions at the lowest level in the managerial chain.

On the other hand, some specialists consider that the low number of verifications leave room for, and cover, fraudulent actions, while the lack of managers' involvement is speculated by both accountants and auditors who become accomplices [Dr.Sharad Kumar, Puşcaş C., Frauda la nivelul companiilor, Contabilitate, expertiza si auditul afacerilor, 2005].

Auditors do not have the obligation to identify fraud but it is obvious that their investigations may reveal an accounting recording that has to be reported.

Romanian literature did not develop the concept of creative accounting, but in Feleagă and Malciu references are made to the fact that it is "usually used to describe the process whereby accounting experts make use of their knowledge to manipulate the figures in the annual accounts".

As a matter of fact we are interested in the link between creative accounting and fiscal fraud - the eventual differences.

There is nothing creative in frauds, they are illegal and there have always existed accounting options no matter if accounting is based on principles, or on rules. Moreover, the flexibility of the options related to the application of accounting policies is added to the subjectivism of the evaluation [Ristea, M., Dumitru, G., Gestiunea şi contabilitatea firmei, Rev. No. 8/2006].
The following question remains open: is accounting able to produce a truth and an objective message?

The idea and the formulation are excessively categorical and unjustly generalizing, even if supported by the scientific experience of the French professor A. Cibert who stated: "there are as many truths as there are holders of information and insofar as it excludes quality, the reducing effect of each measure is unavoidable".

To be even more convincing he resorts to P.Lasseque, B.Colasse and D.Boussard who also admit that the $"<<$ truth $>>$ as told by accountancy is only a filter that allows us to understand a certain reality. Nevertheless, due to the internal coherence that makes both its strength and its weakness, accountancy allows us to get to a formal truth based on a few postulates: conventions, norms, classification rules."

The question "is there an accounting truth?" can be answered in Pirandello's style: "Everyone has one's own truth".

Consequently, since there are different social protagonists, the truth about the accurate image of the financial position and performance must be sought depending on the interests of the generators and the users of information.

For users, the truth supplied by accountants can only be the result of a compromise between expectations and demanding requirements while for generators, a ratio between sincerity and regularity (observance of the fundamental principles and rules).

To sustain the accounting truth, there are a few telling examples of accounting manipulation:

application of the options related to the allowed accounting policies, basic and alternative treatments;

$>$ preferential application of evaluations in accountancy:

$\checkmark$ asset impairment test;

$\checkmark$ revaluation of fixed assets;

$\checkmark$ changing the stock evaluation methods;

$\checkmark$ subjective evaluation of intangible assets and financial securities;

$\checkmark$ modification of depreciation rate; 
$\checkmark$ flexibility of policies regarding the provisions for risks and expenditures;

$\checkmark$ internal prices for assets assignment and assignment prices among the subsidiaries of the same group;

- manipulation of accounts by structuring and delaying real transactions;

- increasing the difference between the book value and the acquisition price, through sub - evaluation of the purchased asset and passing the difference onto the reserves;

- "lease-back" operations, whereby an asset is sold and then rented from the buying company. The effect of such a transaction consists in improving the treasury, reducing the indebtedness rate and increasing the benefit;

- attenuation of receivables losses by subscription of an insurance, which improves the result by the difference between the value of the receivable impairment and the paid up insurance premium;

- issuance of hybrid securities, whereby companies can turn some debts into own capitals;

- assets transfer to another company, along with the debt management, an operation called "accounting disindebtedness".

From an academic perspective, it is to reflect upon the idea according to which the time has come for accounting to take on a really scientific character, i.e. to build a general theory, independent of the application conditions. Such theory must be able to determine applications based on a single reasoning. The axiom will be: there is no science other than general, as there is no truth other than particular [Hoanță, N., Evaziune fiscala, Ed. Tribuna Economică, Bucureşti1997].

\section{SWOT analysis of fiscal evasion}

Fraud is presently considered to be the highest risk for a company, closely related to market, credit, juridical and reputation risks.

Fraud risks generate both direct financial losses and collateral losses at very high levels, namely negative publicity, which damages the company reputation, makes investors lose confidence in the company management, affects the business relations and the employees' morale.

A feedback to this situation comes from the investors who call for the development of anti-fraud mechanisms based on preventive measures (internal audit, efficient risk management) as well as on measures meant to identify frauds in time.

A survey conducted by Global Economic Crime Survey in 2005 [Studiu Universitatea Martin Luther, HalleWittenberg, Germany, 2005,Rev.Audit Financiar, p.3-8] on 3600 international companies shows the following rating of fraud, by categories:

- embezzlement $22 \%$

- financial statement manipulation $19 \%$

- corruption and bribe $\quad 19 \%$

- false claims $15 \%$

- forgery $9 \%$

- money laundering $\quad 7 \%$

- others $9 \%$

The reduction of "non-registered" economy is a source for increasing tax revenues to the states and a means to maintain a competition of accepted rules by the dominant entrepreneurs. This is also about imposing a profitability threshold under which companies should not exist, because there is no fiscal profitability [Guevorkian, K., L'economie non-enregistre, L'Harmattan, Logiques economiques, Paris, 1, p.5-13].

There are many types of nonregistered (underground) businesses that should be identified in order to find their common elements. The question is: "Why there exist underground economy in most of the countries, no matter if they are industrialized countries, countries in transition or developing countries?"

At an international level, the percentage of fiscal evasion, i.e. underground economy, in the GDP, varied in 1995 between $80 \%$ in North Korea and $7 \%$ in Austria, according to some analyses published in different issues of "Le Monde" [Le Monde, October, 1996, p.1-7; 1997, p.48, 93; January,1997, p.3; March, 1998, p.4], as follows:

The reduction of "non-registered" economy is a source for increasing tax revenues to the states and a means to maintain 


\begin{tabular}{|l|l|l|l|}
\hline Country & Percentage & Country & Percentage \\
\hline North Korea & $80 \%$ & Belgium & $20 \%$ \\
\hline $\begin{array}{l}\text { Armenia, } \\
\text { Zair }\end{array}$ & $70 \%$ & Great Britain & $18 \%$ \\
\hline Ukraine & $50 \%$ & Sweden & $17 \%$ \\
\hline $\begin{array}{l}\text { Russia, } \\
\text { Turkey }\end{array}$ & $40 \%$ & $\begin{array}{l}\text { France, } \\
\text { the Netherlands }\end{array}$ & $14 \%$ \\
\hline Serbia & $30 \%$ & Germany & $13 \%$ \\
\hline Croatia & $25 \%$ & United States & $9 \%$ \\
\hline $\begin{array}{l}\text { Hungary, } \\
\text { Italy }\end{array}$ & $23 \%$ & Austria & $7 \%$ \\
\hline
\end{tabular}

by the Japanese workers and the Siberian mines' workers.

Armenia has the same percentage as Zaire, namely $70 \%$, which is due to the lack of interest for a reform of the fiscal system.

For Ukraine, the percentage of $50 \%$ comes from two contradictory sources: the government policy and the pro - Russian businesses.

Italy is a specific case characterized a competition of accepted rules by the dominant entrepreneurs. This is also about imposing a profitability threshold under which companies should not exist, because there is no fiscal profitability [Guevorkian, K.,L'economie non-enregistre, L'Harmattan, Logiques economiques, Paris,]

There are many types of nonregistered (underground) businesses that should be identified in order to find their common elements. The question is: "Why there exist underground economy in most of the countries, no matter if they are industrialized countries, countries in transition or developing countries?"

At an international level, the percentage of fiscal evasion, i.e. underground economy, in the GDP, varied in 1995 between $80 \%$ in North Korea and $7 \%$ in Austria, according to some analyses published in different issues of "Le Monde" [Le Monde, October,1996,p.1-7;1997-pp.48,93; January, 1997, p.3; March, 1998, p.4], as follows:

For North Korea, it seems that this very high evasion percentage is fed by the "good" in China and the infusion of currency

by a very dynamic handicraft sector with over 1.32 million enterprises with an average of 23 employees each, which practice fiscal discretion.

The resulting question is "Who would profit from the underground economy?"

The most interested would be exactly those enterprises that fail to declare, or only partially declare, their business. Another category would be the employees who fail to declare or only partially declare their business and the place of such business; such employees benefit from satisfactory salaries, above the country average, without paying the amounts due for pensions, social contributions, unemployment. Another satisfied category would be the persons having no working permit and last but not least that category of organizations or persons who would charge a fee not to denounce this type of underground economy.

Perhaps at this moment is opportune to compare the two SWOT analyses for the real, registered economy and for the underground non-registered economy.

Registered Economy - SWOT Analysis

\begin{tabular}{|l|l|}
\hline \multicolumn{1}{|c|}{ Strengths } & \multicolumn{1}{c|}{ Weaknesses } \\
- generation of revenues; & - high control costs; \\
- capacity to contract bank loans; & - difficult environmental adaptation; \\
- banking payment facilities; & - mandatory respect for normality; \\
- concentration of possibilities; & - high sensitivity to the environment; \\
- export possibilities. & $\begin{array}{l}\text { - social legislation; } \\
\text { - prohibited activities; } \\
\text { - difficulties in the desire to observe the } \\
\text { intellectual property rights by the non-registered } \\
\text { enterprises. }\end{array}$ \\
\hline \multicolumn{1}{|c|}{ Opportunities } & \multicolumn{1}{c|}{ Threats } \\
- state assistance; & - foreign competition; \\
- development possibilities. & - competition from non-registered enterprises; \\
- reduced flexibility;
\end{tabular}




\begin{tabular}{|l|l|}
\hline & $\begin{array}{l}\text { - reduced public investments due to lack of tax } \\
\text { collection }\end{array}$ \\
\hline
\end{tabular}

\section{Non-Registered Economy - SWOT Analysis}

\begin{tabular}{|l|l|}
\hline \multicolumn{1}{|c|}{ Strengths } & \multicolumn{1}{c|}{ Weaknesses } \\
- generation of revenues (even if not registered); & - impossibility to contract bank credits; \\
- rapid identification of requirements; & - no possibility for growth; \\
- no social legislation; & - difficulties in using banking systems; \\
- no normality observance; & - difficult access to certain activities; \\
- lower environmental sensitivity; & - impossibility to make publicity; \\
- no respect to the intellectual property right & - no access to justice; \\
\hline \multicolumn{1}{|c|}{ Opportunities } & \multicolumn{1}{c|}{ Threats } \\
- environmental adaptability & - state pressure for registration; \\
- transformation into registered enterprises & $\begin{array}{l}\text { - increased protection costs; } \\
\text { - lack of young people training. }\end{array}$ \\
\hline
\end{tabular}

The state is responsible for transforming the non-registered economy into registered economy, to measure the country's level of development. The solution is to either ignore it or try an eradication by constraint. It would be also possible that after a minimal identification, such non-registered enterprises should be helped to become profitable through the transparent commissions that provided the tolerance and the constraint to be registered.

International recommendations are that all standard methods for control and fight against money laundering should be enforced by the multinational companies as well as by accountants, financial auditors, lawyers and other categories of liberal trades.

It is the duty of each of these categories of persons, where a suspicion arises concerning their clients' illegal activities, to immediately report such activities to the financial regulatory organizations set up for this purpose by the countries' governments.

To satisfy their information needs, decision makers must resort to new information sources. That is why professions such as that of accountant, auditor and tax adviser are called to create new instruments meant to eliminate the information limits of financial statements.

\section{References:}

[1] Cernuşcă, L., Politici contabile de întreprindere, Editura Tribuna Economică

[2] Griffith, I., Creative Accounting, London: Sidgwick \& Jackson

[3] Nasser, K., Creative Financial Accounting: It's nature and use, Hemel Hempstead: Prentice Hall

[4] Bertolus, J., L'art de truquer un bilan, Science \& Vie economie, ${ }^{\circ}$ 40, June, 1988

[5] Dr.Sharad Kumar, Puşcaş C., Frauda la nivelul companiilor, Contabilitate, expertiza si auditul afacerilor, 2005

[6] Ristea, M., Dumitru, G., Gestiunea şi contabilitatea firmei, Rev. No. 8/2006

[7] Hoanță, N., Evaziune fiscala, Ed. Tribuna Economică, Bucureşti, 1997

[8] Studiu Universitatea Martin Luther, Halle-Wittenberg, Germany, 2005, Rev. Audit Financiar

[9] Guevorkian, K., - L'economie non-enregistre, L'Harmattan, Logiques economiques, Paris, 1998

[10] Le Monde, 1996-1998 